\title{
1.ま之がき
}

同

正員。岩崎敏男

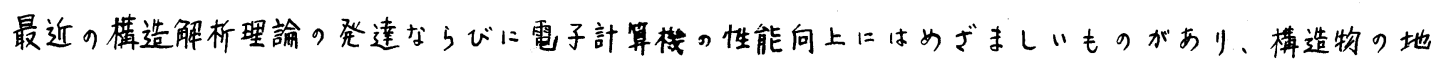
震応答解析においては、相当複雑なモデルを設定した精密な解析が行えるようになってきた。一方応 答解析の入力となるべき实耧造物の振動性状ならでに解析結果の检証となるべき实際の地震時の挙動

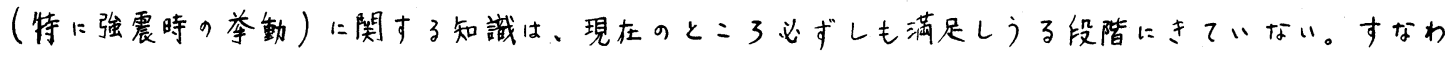
与解析モデル（設定法々その物理定数の与え方）なうい゙に地震力の与え方に関してあいまいな点が少 なくない。:のため解析の筙团や焦点をしぼるのが難しく、また解析結果を道磪に判断するためには 高度の予備知識を必要とするのが現状といえよう。

当所ではかかる問題の解決の一助とするべく、以前から实物橋梁の振動实験を实施するとともに昭

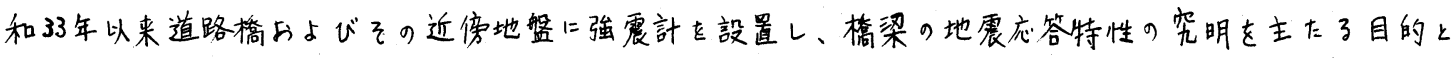
した強震䚁測を突施してきた。昭和39年以後は新渴地震による土木構造物の震害に鑑4建設省が立案

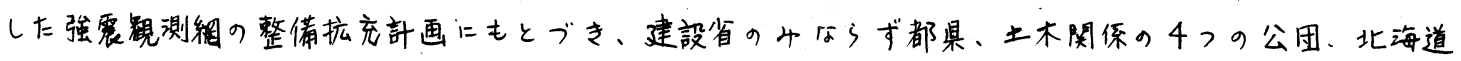

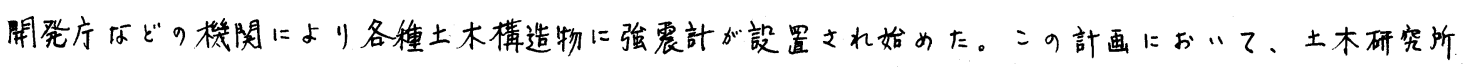

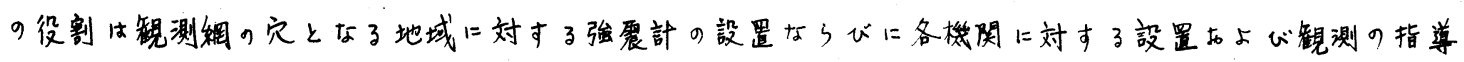

得うれた記睩の收集、保管、復军記睩の刑行乙配布ならびに解析の作丵を担当することとなってい 了。

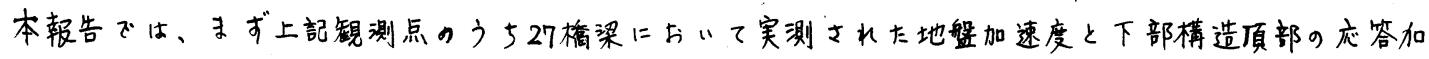
速度の関係を示し、ついで特定の椅梁について突测結果をや也詳述しさ引に一部については庞答解析 の結果との対比を行つたものである。

\section{27 椎梁における地震応答の一般的倾向}

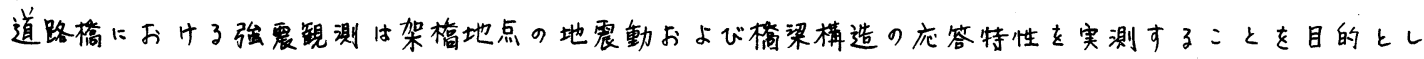
、すでに56榜において实施されている。一般に模造物に近接しかつ架設地点々同種の地盤条件をもつ

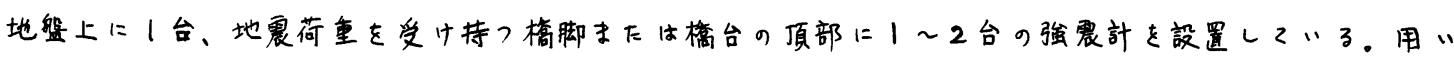

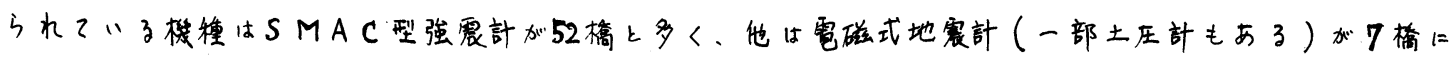

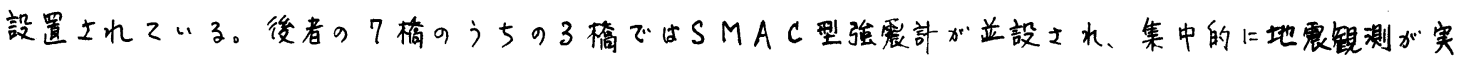
施士れている。

上記56橋のうち表、1に示す28简にちいては地震応答特性を解明する上に有奻な強震記错がすでに得 られている。他の钼测点においても多数記録が得られているが、田加速度が小さくて芜取y精度が任

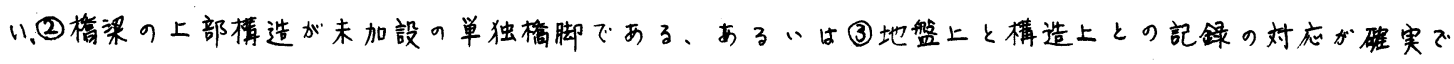
ない、などの理由のためここでは割爱きれている。

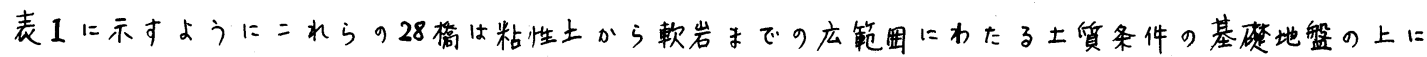

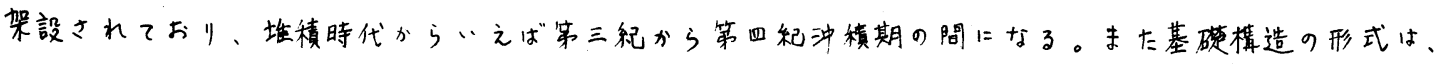




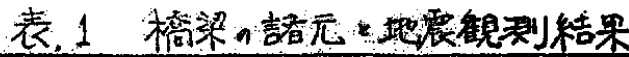

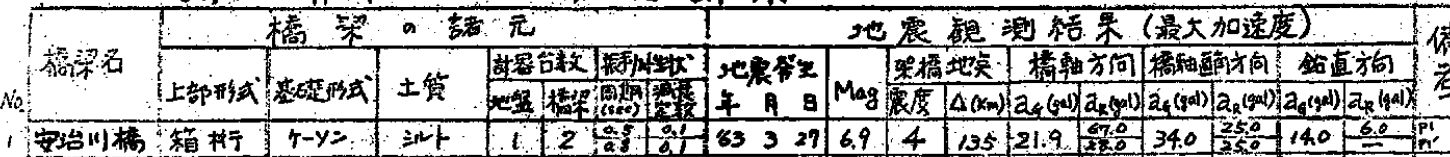

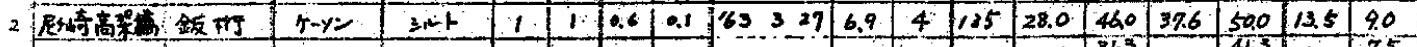

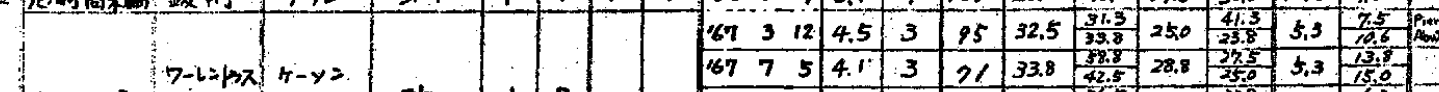

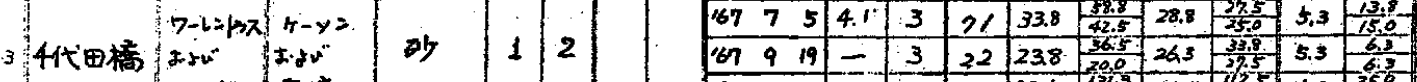

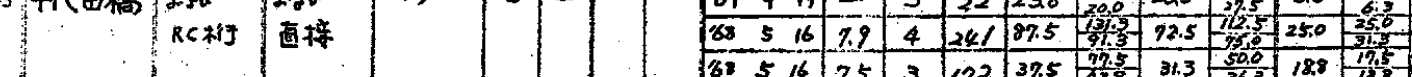

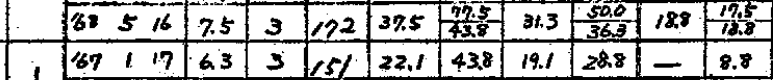

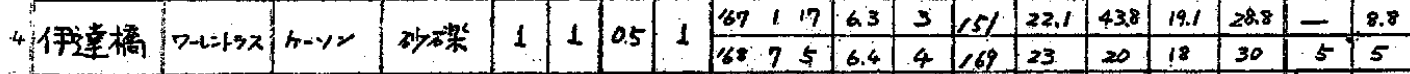

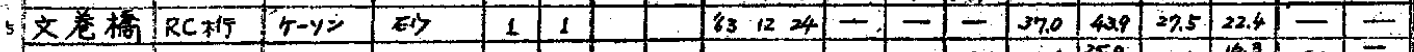

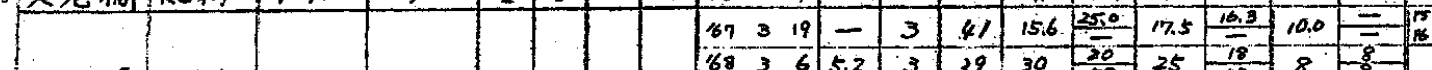

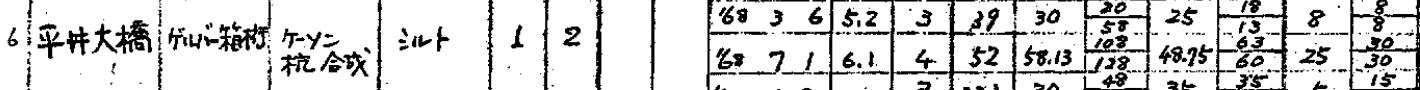

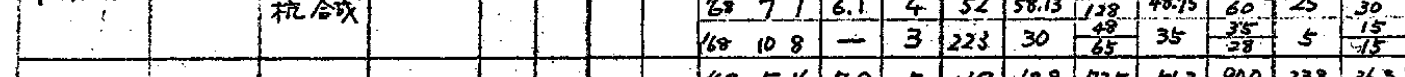

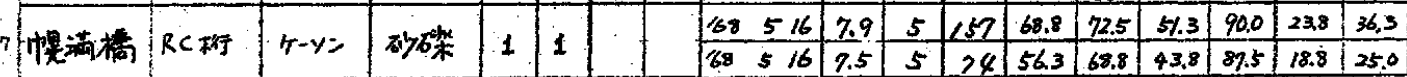

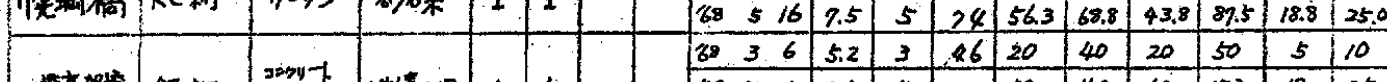

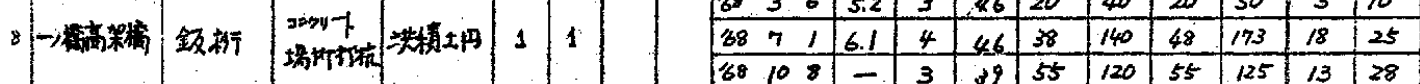

\begin{tabular}{|l|r|r|r|r|r|r|r|r|r|r|r|}
\hline & 38.21 & 6.1 & 4 & 39 & 22.5 & 50.0 & 20.0 & 25.0 & 10.0 & 5.0 \\
\hline
\end{tabular}

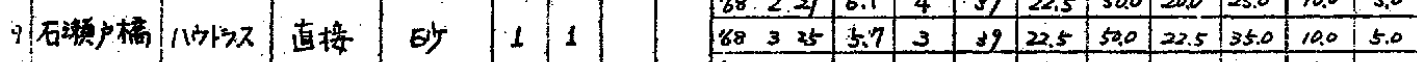

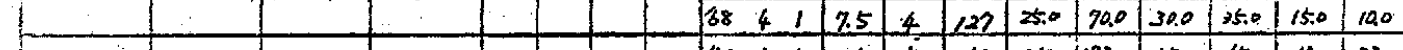

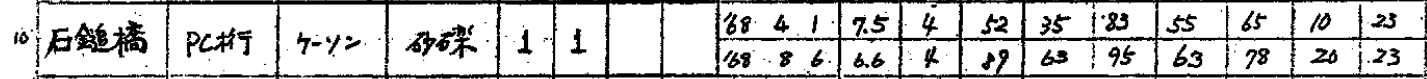

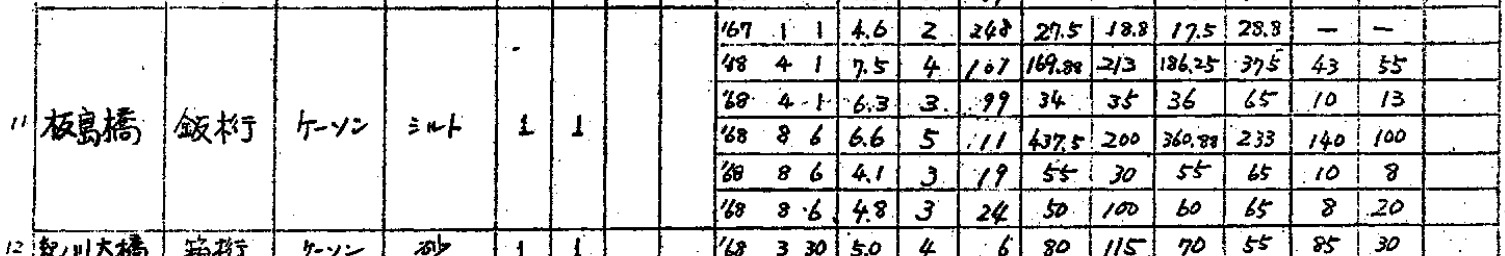

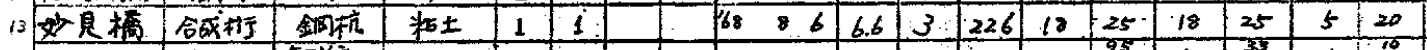

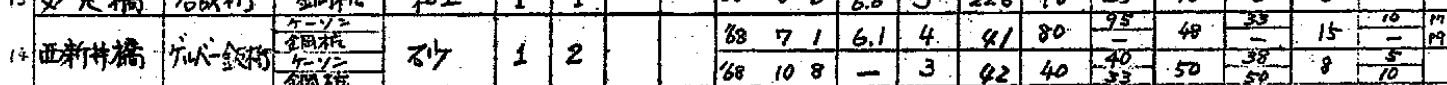

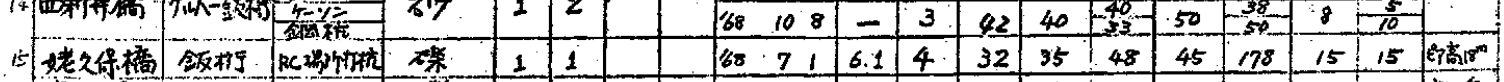

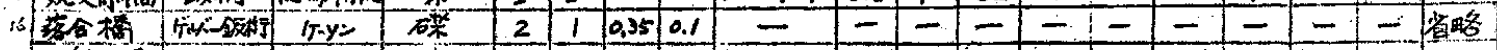

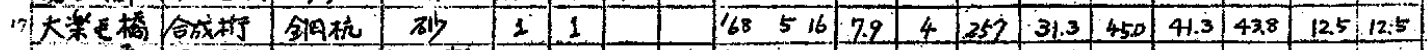

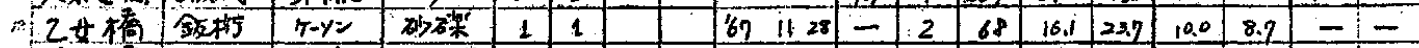

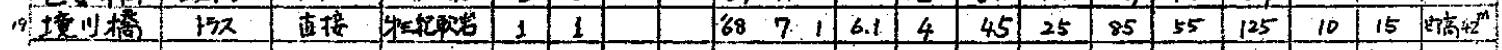

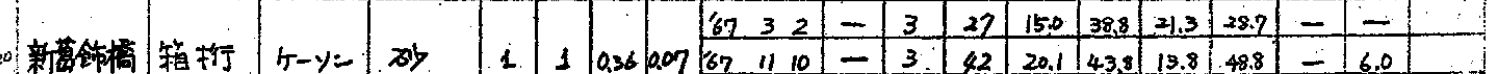

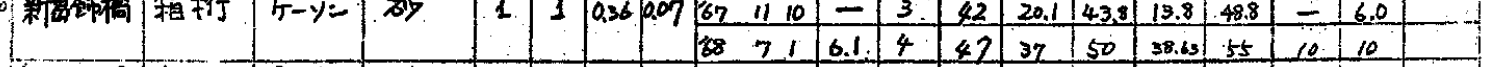

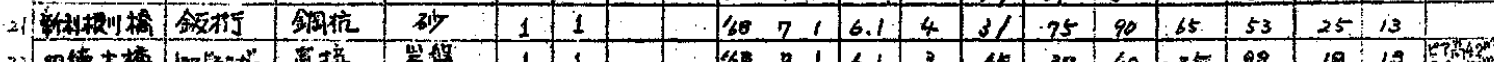

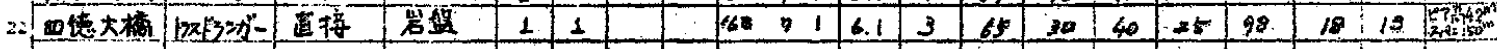

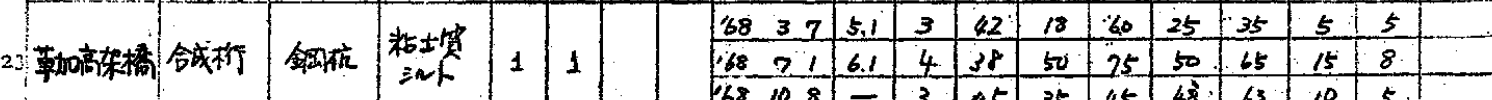

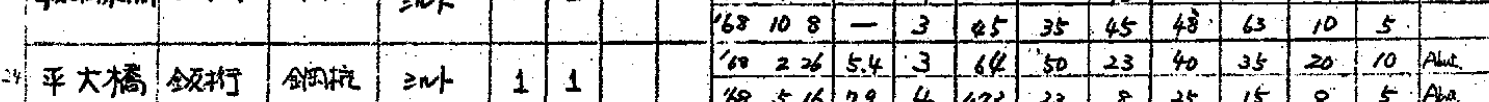

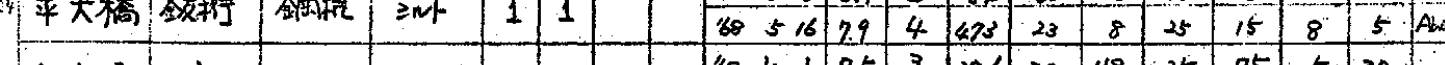

25! 高津檍 合成括

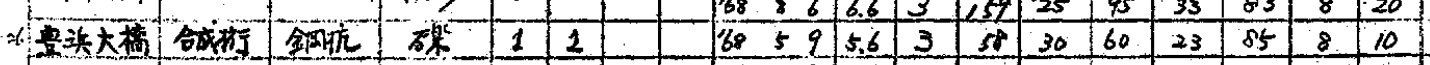

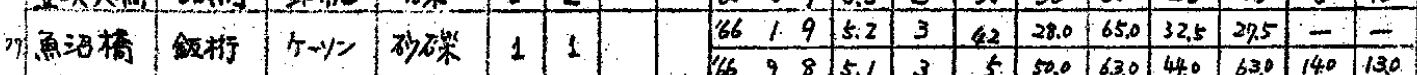

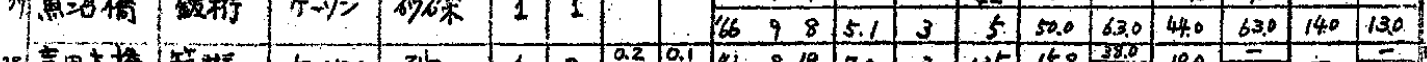

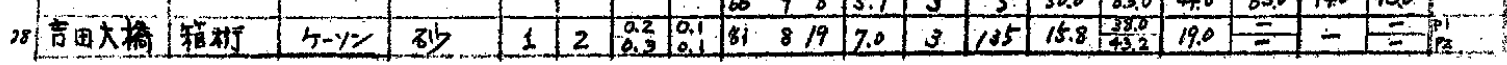




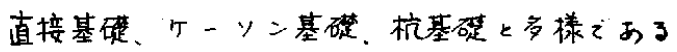

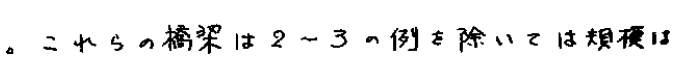
我国によける一般的垉のであり、橋脚的上上

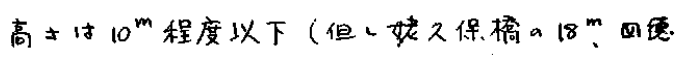

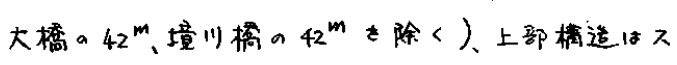

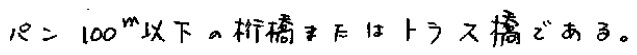

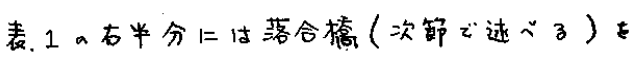

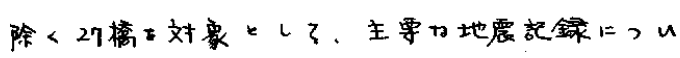

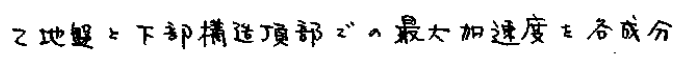

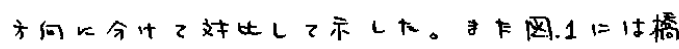

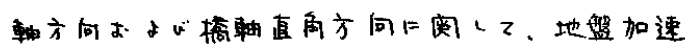

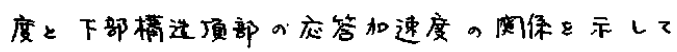

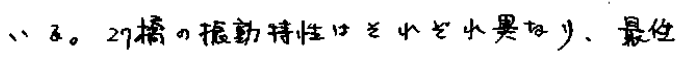

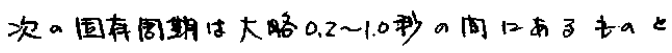

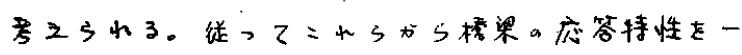

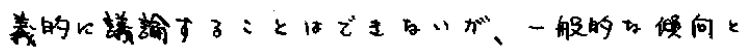

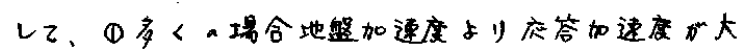

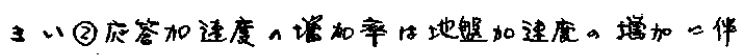
つて任下てる:くの乙桌があげられる。

3. 松代地震による落合檍の地震広答

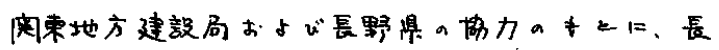

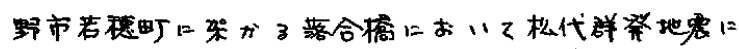

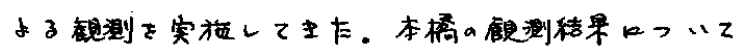

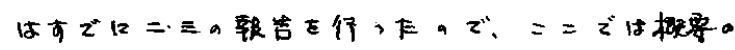
为揢述することロする。

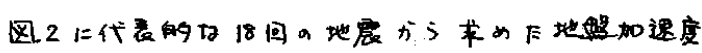

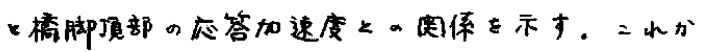
b) 近似的に,

$$
a_{R}=8.33 a_{G}^{0.50}
$$

$\left(==1 ， a_{G}\right.$ は地船加速度 a最大值， $a_{R}$ 応答加 速度的最大值でともに gal 单位)るる实梌式が得

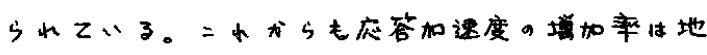

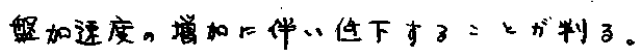

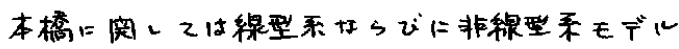

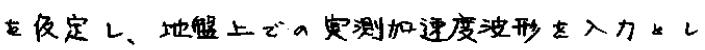

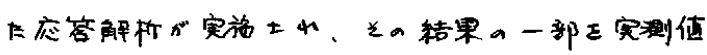

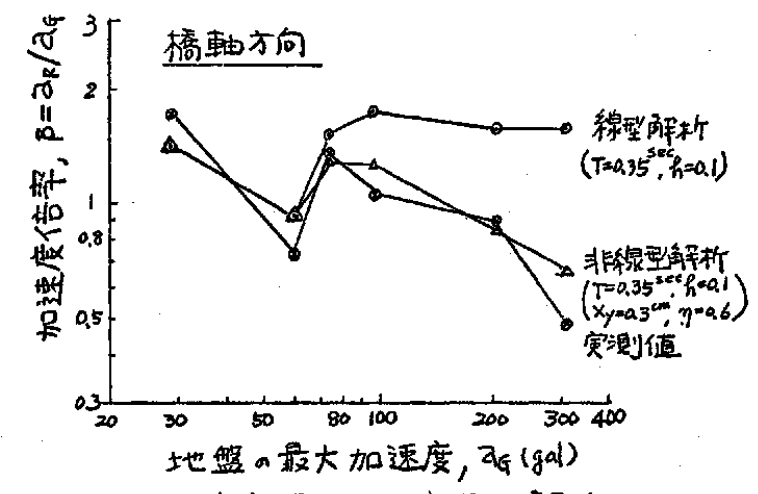

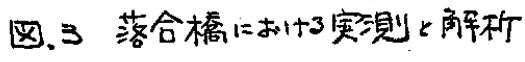

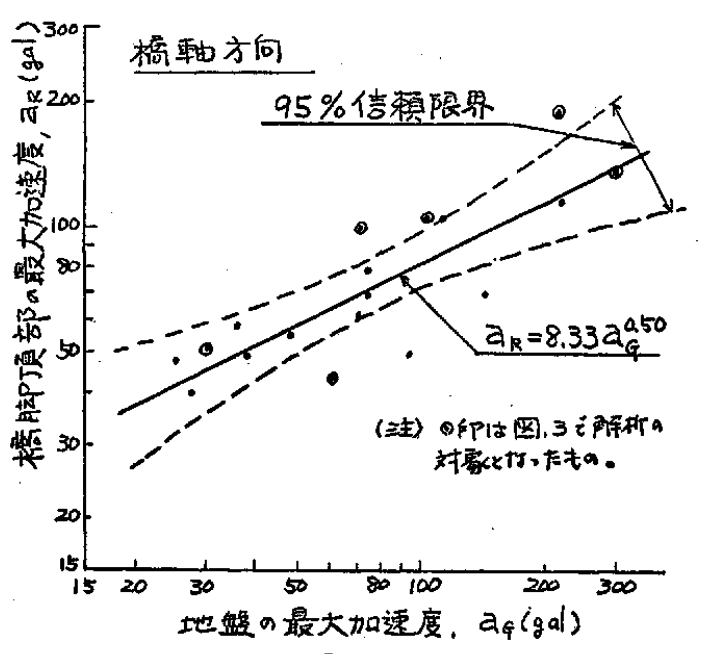

四.2落合橋a突测結果

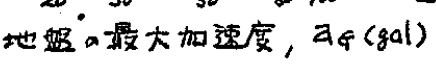

四1.27橋における地震観㰾結果

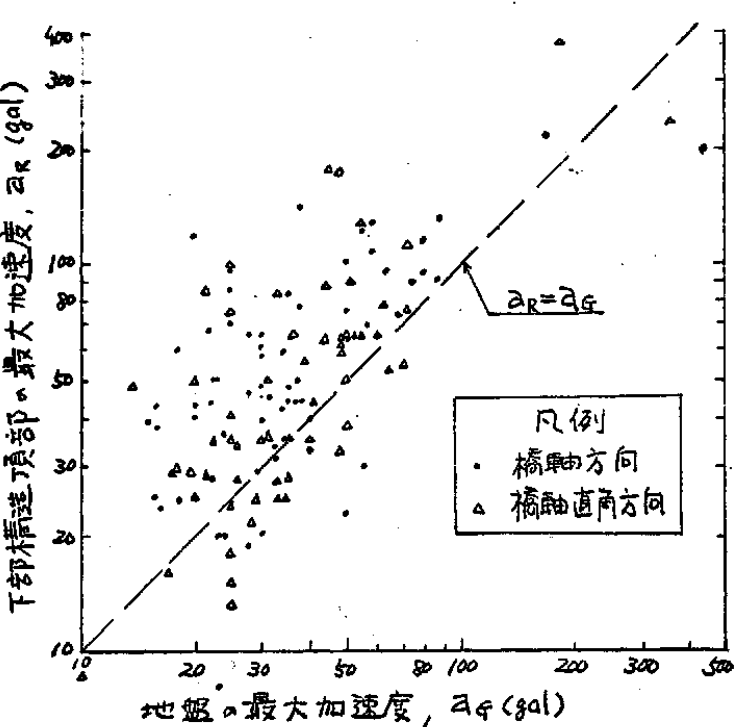




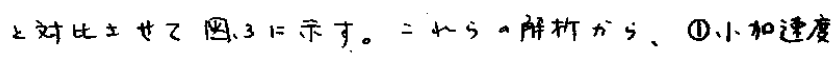

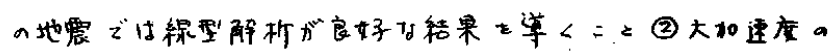

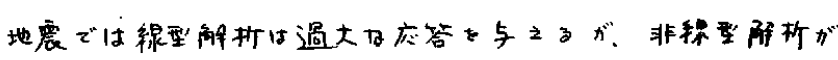

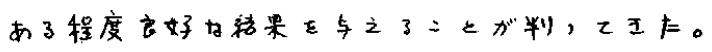

4、新葛飾橋によける开筒槁脚。地震庝答

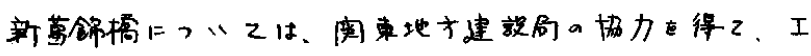

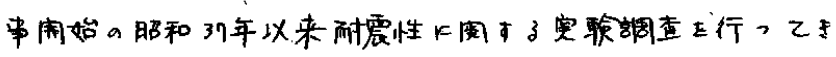

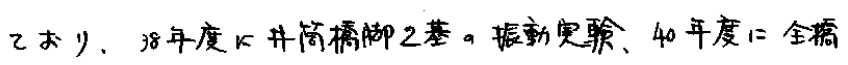

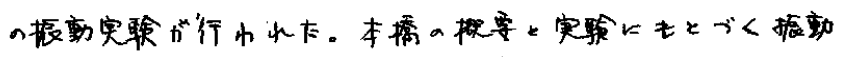

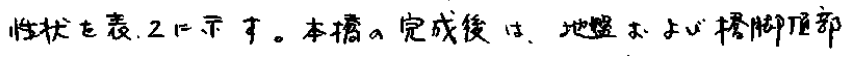

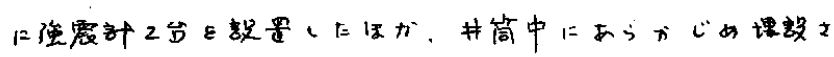

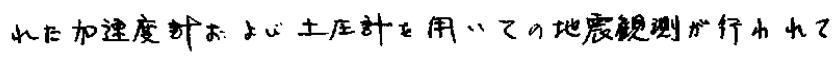

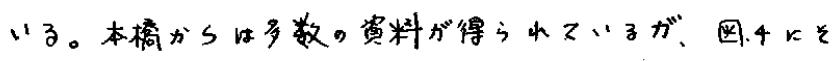

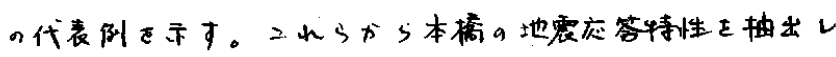
表:2 新葛领橋a概要

\begin{tabular}{|c|c|c|}
\hline 管 轄 & \multicolumn{2}{|c|}{ 建設省闺束地方建放局 } \\
\hline & \multirow{2}{*}{\multicolumn{2}{|c|}{ 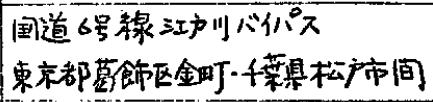 }} \\
\hline 直 & & \\
\hline 格 & \multicolumn{2}{|c|}{ 一等檍 } \\
\hline 長 & \multicolumn{2}{|c|}{$442^{m}=0.55+4055+0.9+4055+0.55$} \\
\hline 巾 & \multicolumn{2}{|c|}{$17.7^{\mathrm{m}}=1.85+14+1.85$} \\
\hline 上 部 & \multicolumn{2}{|c|}{ 金周籍析 4 往间連綍 2 連 } \\
\hline 下 部 & \multicolumn{2}{|c|}{ 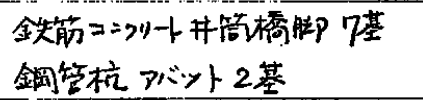 } \\
\hline 媇計震度 & \multicolumn{2}{|c|}{ 水平 0.25 , 鉛遖 0.1} \\
\hline 土筧条件 & \multicolumn{2}{|c|}{ 砂 $(N>20)$} \\
\hline \multirow{4}{*}{$\begin{array}{l}\text { 振敦性状 } \\
\text { (上部架設後) }\end{array}$} & 基圭国有周期 & 0.36 秒 \\
\hline & 振憅モード & ロッキニグ \\
\hline & 減衰定数 & 0.066 \\
\hline & 動的 K值 & $4.2 \mathrm{~kg} / \mathrm{cm}^{3}$ \\
\hline
\end{tabular}

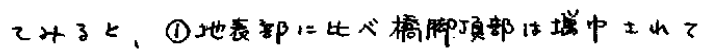

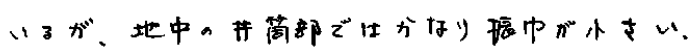

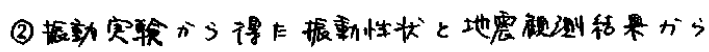

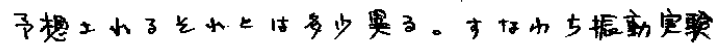

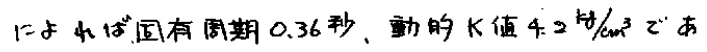
了。に对し、地震短测では卓越周期 0.50 秒、新的 任 $2.0 \mathrm{k} / \mathrm{cm}^{3}$ ごおる。ガか子理象ガ起二る要因上

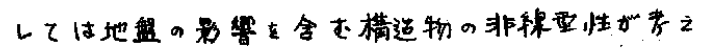
られるメンろであるガ、持に禹者における筒部

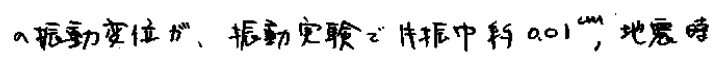

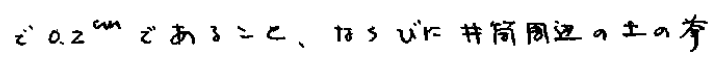

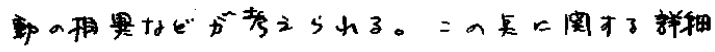

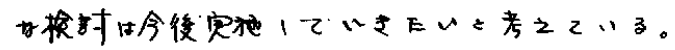

\section{5. 繥諭}

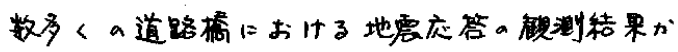

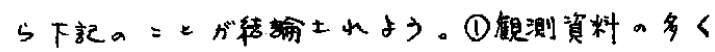

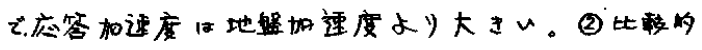

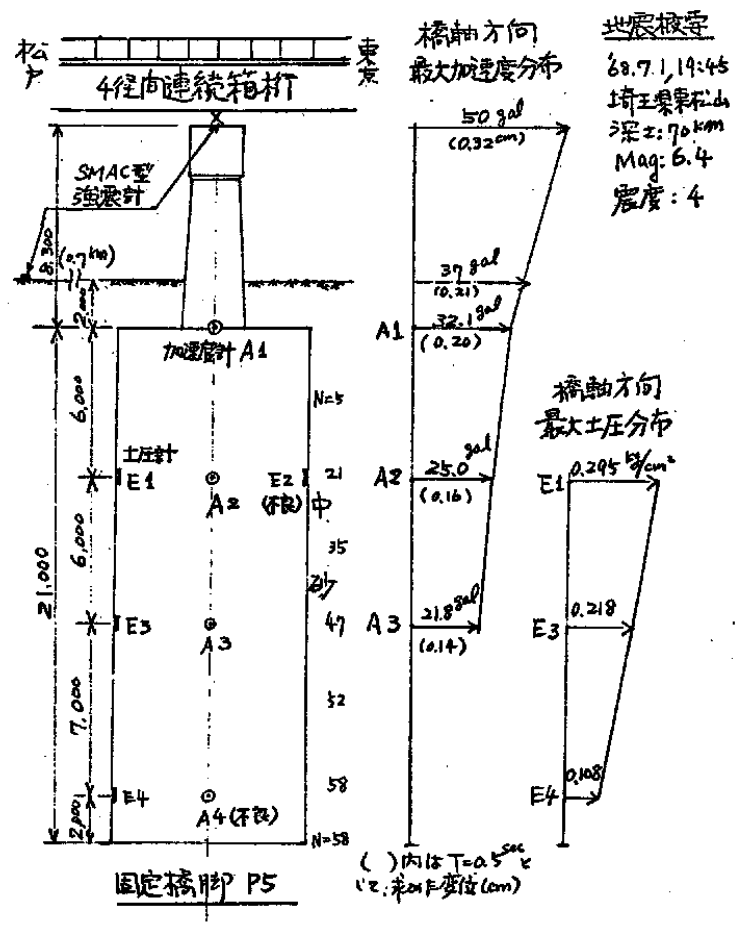

図.4新葛飾橋ごの地震観測結果

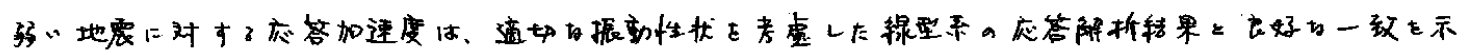

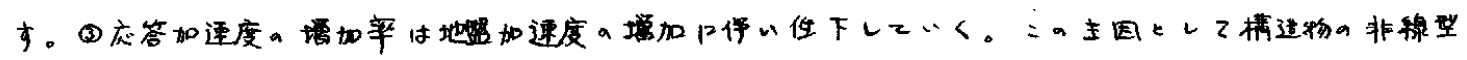

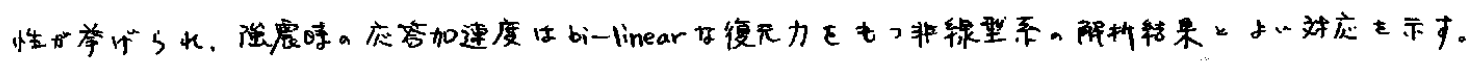
(4)地中部分a加速度的地表部比し任下する。 